from those known to have infection but from those travelling or coming to hospital in the earlier phases of the infection, when they may merely feel unwell and have some fever, possibly of slight degree.

1 British Medical fournal, 1972, 4, 253.

2 Woodruff, A. W., et al., British Medical fournal, 1973, 3, 616.

3 The Times, 14 January, 1975.

4 W.H.O. Weekly Epidemiological Record, 1974, 49, 341.

\section{Back from the Brink}

The Government has finally recognized that its collision course with consultants could cause irreparable damage to the Health Service. Last week in Parliament (18 January, p. 159), Mrs. Castle seemed to be stepping back from the brink of confrontation and a subsequent letter to the B.M.A.'s Secretary strengthened this impression (p. 224). After discussing these latest developments the Central Committee for Hospital Medical Services (p. 225) decided to accept her suggestion for talks about talks. But until she gives evidence of her good intention senior hospital doctors have been asked to continue working to their contracts.

To unite in indignation over ill-considered Government policy was relatively easy-and, as reports from the country (including an unprecedented letter on p. 226 from London teaching hospital staff) show, this dispute has brought consultants together as never before. But it is less easy to agree on the next step now that the negotiating impasse has apparently been broken. Before deciding on solutions, however, consultants should remember why they are facing the Government in anger.

Most doctors whole-heartedly support the concept of the N.H.S. and wish it to continue-though some will argue that its present troubles were inherent. Certainly the country's persisting economic weakness has steadily undermined the staffs' ability to maintain the delicate balance between resources and demands. As Sir Rodney Smith, President of the Royal College of Surgeons, writes on p. 209, "Extreme underfinancing" and the "catastrophic decline in morale among all manning the N.H.S." are endangering patient care.

The catalogue of woe has been made tedious by repetition: more patients and more work-contrasted with a lack of junior staff, of nurses and of paramedical staff, of equipment, and, all too often, of imagination. Some executive actions are almost beyond belief, as doctors in Leeds will confirm where the Womens' Hospital was demolished before a badly needed replacement was available. Now the capital expenditure cuts have meant no replacement and the "facilities for gynaecological patients are worse than they were in 1948."1 Such incidents drive doctors to despair, and when to their professional worries are added personal financial stresses their tolerance snaps.

The widespread dissatisfaction over the past few years led to the profession trying to negotiate a contract for consultants that would set a limit on the ever-rising work load and provide an adequate reward. After two years little progress had been made with the Health Departments at official level. Discussions were finally lifted to Ministerial level with Dr. David Owen chairing a working party charged with finding a quick solution. Advances were made until the Government's blatantly ideological approach to the peripheral issue of private beds disrupted the proceedings.

Annoyed though doctors were, they restarted the talks because a solution to the contract difficulties was urgent. But when before Christmas Mrs. Castle presented her Government's final proposals the content of the package and the manner of its delivery so infuriated the consultants' leaders that they advised their colleagues to work to contract.

The propaganda battle that followed has scarcely enlightened the issues at stake, which are defined in the letter from the President of the R.C.S. Nevertheless, the Government's December package has now been withdrawn and presumably consultants are back where they were. But time is short and the over-riding aim, as inflation worsens, must be to get consultants, particularly the younger ones, a substantial increase in their pay. To negotiate and price a new contract would mean an unacceptable delay so that the C.C.H.M.S. has decided to press ahead with evidence for the April review based on the existing contract. If it is possible in the time some easily made improvements to the contract (for instance, payments for night calls) would be sought as well. This is a pragmatic course that should appeal to most consultants, but the C.C.H.M.S. is rightly wary of Mrs. Castle's suggestion to submit in February a "general outline of evidence on the pricing of a new contract" for fear of prejudicing a substantial award in April. But what of the future ? Have the sanctions and their attendant tribulation been to no avail ?

The answer is No. The Government now knows the consultants' strength and their opposition to a whole-time service. The public has had another stark demonstration of the Health Service's weaknesses. Finally, consultants have been reminded how rewarding an occupation medicine can be when practised at a measured pace. The profession has also been warned of the use which a Government could make of a closed contract.

Inevitably the dispute has revealed more clearly differences of opinion among consultants but even these can be used to good effect. There has been plenty of opportunity in the past two years or so to discuss the B.M.A.'s 10-session contract proposals, which were endorsed by the National Conference of Hospital Staffs in $1972 .{ }^{4}$ The events of the last month or so have not suddenly rendered its principles obsolete. Nevertheless, no doubt Dr. C. E. Astley, Dr. E. B. Lewis, and their colleagues can use the recent experiences and the volume of comment from doctors to improve the proposals. If Mrs. Castle demonstrates her good faith in the forthcoming exploratory talks and sanctions are withdrawn negotiations can resume. But consultants are impatient for results. This time the Government cannot afford to let the talks fail for the whole future of the N.H.S. is at stake.

\footnotetext{
1 Yorkshire Post, 13 January, p.80.
2 British Medical fournal Supplement, 1972, 3, 60.
} 